\title{
Engineering Disease-Resistant Cassava
}

\author{
Z.J. Daniel Lin, Nigel J. Taylor, and Rebecca Bart \\ Donald Danforth Plant Science Center, St. Louis, Missouri 63132, USA \\ Correspondence: rbart@danforthcenter.org
}

Manihot esculenta Crantz (cassava) is a food crop originating from South America grown primarily for its starchy storage roots. Today, cassava is grown in the tropics of South America, Africa, and Asia with an estimated 800 million people relying on it as a staple source of calories. In parts of sub-Saharan Africa, cassava is particularly crucial for food security. Cassava root starch also has use in the pharmaceutical, textile, paper, and biofuel industries. Cassava has seen strong demand since 2000 and production has increased consistently yearover-year, but potential yields are hampered by susceptibility to biotic and abiotic stresses. In particular, bacterial and viral diseases can cause severe yield losses. Of note are cassava bacterial blight $(\mathrm{CBB})$, cassava mosaic disease $(\mathrm{CMD})$, and cassava brown streak disease (CBSD), all of which can cause catastrophic losses for growers. In this article, we provide an overview of the major microbial diseases of cassava, discuss current and potential future efforts to engineer new sources of resistance, and conclude with a discussion of the regulatory hurdles that face biotechnology.

\section{OVERVIEW OF MAJOR CASSAVA DISEASES}

Cassava Mosaic Disease

Cassava mosaic disease (CMD) was first identified in 1894 in what is now modern-day Tanzania, and by 1950 could be found across almost all of sub-Saharan Africa. The first report of the disease in India was made in 1956, followed by its discovery in Sri Lanka in 1986 (Patil and Fauquet 2009). In 2015, CMD was found in Cambodia, indicating a concerning expansion of the disease into Southeast Asia (Wang et al. 2016). Symptoms of CMD include chlorotic, mosaic patterning of leaves, along with abnormal leaf development that manifests as curling and twisting of leaflets (Fig. 1B). CMD has been reported to cause root yield losses of up to $82 \%$ in some studies (Owor et al. 2004). Coupled with its pervasiveness, this has earned CMD recognition as one of the most economically important plant viral diseases in the world (Scholthof et al. 2011; Food and Agriculture Organization of the United Nations 2013).

The causative agents of CMD are cassava mosaic geminiviruses (CMGs), which are vectored by the whitefly Bemisia tabaci (Legg et al. 2015; McCallum et al. 2017; Rey and Vanderschuren 2017). CMGs are single-stranded DNA viruses of the genus Begomovirus, family Geminiviridae. The genomes of CMGs are small, circular, and bipartite with separately packaged DNA-A and DNA-B molecules (each $\sim 2.7 \mathrm{~kb}$ ) that together have eight to nine genes encoding multifunctional proteins. Geminiviruses are often found as mixed infections in plants, which when coupled with a propensity for recombina-

Editor: Pamela C. Ronald

Additional Perspectives on Engineering Plants for Agriculture available at www.cshperspectives.org

Copyright (C) 2019 Cold Spring Harbor Laboratory Press; all rights reserved; doi: 10.1101/cshperspect.a034595

Cite this article as Cold Spring Harb Perspect Biol 2019;11:a034595 

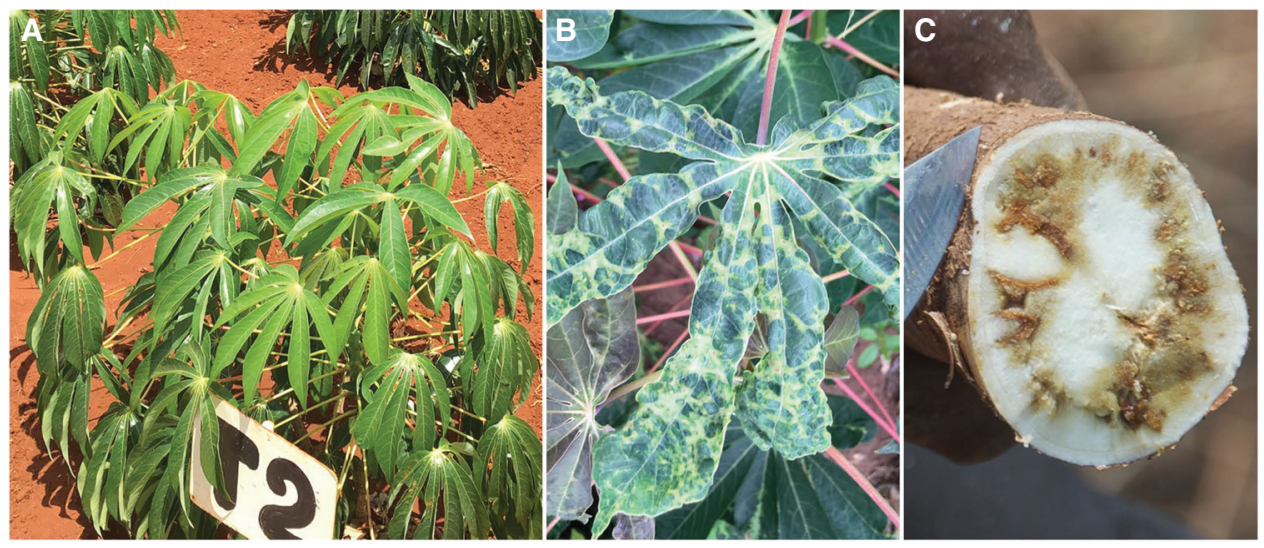

Figure 1. Effects of viral diseases on cassava. (A) Healthy cassava grown in a test plot. (B) Cassava leaves showing developmental defects associated with cassava mosaic disease. $(C)$ Cross-section of a cassava storage root revealing brown necrotic tissue caused by cassava brown streak disease.

tion allows for the emergence of new virus species and variants (Hanley-Bowdoin et al. 2013). To date, nine species account for CMD found in Africa, whereas two other species are present in Asia (Rey and Vanderschuren 2017).

Three types of genetic resistance have been described for CMD, called CMD1, CMD2, and CMD3. None of the underlying genetic determinants have been identified. CMD1 is thought to be polygenic, whereas CMD2 segregates as a dominant single locus. CMD2 and CMD3 both map to the same arm of chromosome 12. (For a more detailed summary of CMD and associated resistance, see Akano et al. 2002; Legg and Fauquet 2004; Wolfe et al. 2016.)

\section{Cassava Brown Streak Disease}

Like CMD, cassava brown streak disease (CBSD) has a long history in sub-Saharan Africa and was first reported in 1935 (Patil et al. 2015; Rey and Vanderschuren 2017). Historically, the disease was confined to the coastal lowlands of eastern sub-Saharan Africa; however, during the past two decades, CBSD has spread to East and Central Africa's Great Lakes region (Storey 1936). The virus is spread locally by B. tabaci, but distributed over long distances by transport of infected planting materials. The disease is named for brown streaking of cassava stems but also causes leaf chlorosis, reductions in storage root yield, and necrosis within the storage roots (Fig. 1C). Losses of up to $70 \%$ have been reported, highlighting the current impact of CBSD and potential damage should the epidemic continue its spread toward the populous, high cassava production countries of West Africa (Hillocks et al. 2001).

CBSD can be caused by individual or simultaneous infection with Cassava brown streak virus (CBSV) or Ugandan cassava brown streak virus (UCBSV) (Hillocks et al. 2001; Tomlinson et al. 2018). These are positive-sense, singlestranded RNA viruses belonging to the genus Ipomovirus of the family Potyviridae. In general, viruses of Potyviridae (potyvirids) have genomes $\sim 10 \mathrm{~kb}$ in length that encode a polyprotein that undergoes proteolytic processing to generate 10 mature products (Revers and García 2015). Ribosomal frameshifting allows for the production of an additional movement protein (Rodamilans et al. 2015). Potyvirids account for almost a quarter of all known plant viruses (Wylie et al. 2017). As such, potyvirid-plant pathosystems have been heavily studied.

\section{Cassava Bacterial Blight}

Cassava bacterial blight $(\mathrm{CBB})$ is caused by the Gram-negative, bacterial pathogen Xanthomo- 
nas axonopodis pv. manihotis (Xam) and occurs in all cassava growing regions across the globe (López and Bernal 2012). (For an overview of historical incidence and severity of CBB, we refer readers to several research articles, reviews, and book chapters; Hillocks and Wydra 2002; Onyeka et al. 2008; Verdier et al. 2012; Fanou et al. 2018.) The main theme of this literature is that, although CBB is recognized as a common disease of cassava, disease incidence and severity is spatially and temporally variable and difficult to predict. For example, Banito and colleagues attempted to correlate $\mathrm{CBB}$ severity to specific agro-ecological zones and/or different cassava varieties but found a high degree of variety $\mathrm{x}$ location variability (Banito et al. 2008). The sporadic nature of $\mathrm{CBB}$ epidemics has confused scientists for decades. Significant genetic diversity exists among pathogen isolates; however, so far, this diversity has not been tied to disease severity variability in the field (Restrepo et al. 2000; Wydra et al. 2004; Bart et al. 2012). A favored hypothesis is that Xam remains dormant on debris, in the soil, or survives on alternative hosts, such as weeds (Fanou et al. 2017). When environmental conditions are favorable, CBB epidemics will occur. Unfortunately, the parameters that define "conducive environmental conditions" have yet to be discovered. Effect on yield has also been difficult to assess because fields infected with $\mathrm{CBB}$ are often also suffering from viral and/or fungal diseases. However, a recent report estimated that $\mathrm{CBB}$ could result in a $34 \%$ reduction in yield when comparing uninfected versus infected cassava fields (Fanou et al. 2017, 2018). In the same report, cassava variety TMS 30572 was shown to have mild tolerance, but the investigators caution that there is a high genotype $\mathrm{x}$ environment $(\mathrm{GxE})$ interaction and that this uneven disease pressure makes screening for tolerance in the field difficult. Regardless, Soto Sedano and colleagues recently report five quantitative trait loci (QTLs) tied to strain-specific resistance derived from TMS 30572. The QTLs were discovered from 117 F1 sibs and with phenotyping performed at two locations and in the greenhouse. Here again, strong GxE interaction was observed (Soto Sedano et al. 2017).
Like many other Xanthomonad pathogens, Xam injects 20 to 30 type 3 effector (T3E) proteins into cassava cells during infection. These proteins are collectively responsible for dampening basal immune responses and inducing susceptibility. The latter is partially accomplished via a specific class of T3Es, the transcription activator-like (TAL) effectors. The vast majority of TAL effector-induced genes have yet to be characterized; however, SWEET sugar transporters and pectate lyases are confirmed to play a role in induced susceptibility (Cohn et al. 2014, 2016).

\section{Other Diseases of Cassava}

In addition to CMD, CBSD, and $\mathrm{CBB}$, several fungal diseases affect cassava including Cercospora spp. and Colletrotrichum spp. (Anthracnose) (Hillocks and Wydra 2002). Leaf spot diseases are considered among the most common fungal diseases of cassava with disease symptoms observed as spots on the lower canopy of mature plants. The impact of these diseases on cassava yields has not been extensively evaluated.

Two additional diseases are worth noting: cassava frogskin disease (CFSD) and cassava witches' broom (CWB). Both are putatively attributed to a unique class of bacterial pathogens known collectively as phytoplasmas (Hogenhout et al. 2008). Although CMD and CBSD are confined to Africa (recently, to Asia for CMD), CFSD has only been reported in Central and South America. CWB has been reported in Asia, Africa, and Latin America (Arocha et al. 2009; Alvarez et al. 2013; Flôres et al. 2013). Relatively little is known about CWB disease, although incidence can be high in commercial fields (Alvarez et al. 2009).

\section{OPPORTUNITIES TO ENGINEER DISEASE RESISTANCE}

Engineering Resistance against Viruses through RNA Interference

Historically, biotechnological approaches to engineering virus-resistant plants relied on an approach termed pathogen-derived resistance 
Z.J.D. Lin et al.

(PDR) (Lindbo and Falk 2017; Rosa et al. 2018). It was observed that transgenic expression of certain viral genes in a plant could confer resistance or attenuated susceptibility (Lindbo and Falk 2017). Certain instances of PDR were found to involve expression of nontranslatable transcripts, suggesting an RNA-mediated silencing mechanism (Lindbo and Dougherty 1992a,b). Coupled with the investigation of transgenemediated silencing and the discovery of RNA interference (RNAi), it is now understood that RNAi is the likely mechanism underlying many instances of PDR (Lindbo and Falk 2017; Rosa et al. 2018).

In eukaryotes, RNAi is an RNA-mediated mechanism of regulating gene expression and antiviral defense. Double-stranded RNA (dsRNA) is recognized and cleaved by Dicerlike (DCL) proteins into 21-, 22-, and 24-nt small-RNA (sRNA) duplexes that are loaded onto a multiprotein RNA-induced silencing complex (RISC) in which one strand of the duplex guides the RISC complex to a specific sequence-complementary target RNA (Borges and Martienssen 2015). This target is either degraded or subjected to translational repression. dsRNA that induces gene silencing comes from a variety of sources. Depending on the dsRNA source, the resulting sRNA can be classified as either small-interfering RNA (siRNA) or microRNA (miRNA). siRNAs are derived from plantendogenous or exogenous RNA species with extensive base-pair complementarity; examples include dsRNA produced during viral replication, independent transcripts with sequence complementarity, plant RNA-dependent RNA polymerase-derived dsRNA, and individual transcripts with extensive self-complementarity that result in hairpin-loop structures (hpRNA). miRNAs, in contrast, are exclusively produced from nonprotein-coding MIRNA genes. MIRNA transcripts have stretches of self-complementarity that result in folding into specific structures recognized by DCL proteins.

As viruses are obligate intracellular parasites that proliferate in cellular compartments also populated with RNAi machinery, viral diseases are particularly amenable to control using RNAi. RNAi strategies have been shown to be effective against potyviruses and geminiviruses infecting squash, papaya, potato, plum, and common bean, suggesting that this technology is a feasible biocontrol strategy against $\mathrm{CMD}$ and CBSD (Rosa et al. 2018). siRNA- and miRNAbased strategies exist, and implementation along with the unique advantages and disadvantages of both approaches have been extensively reviewed (Carbonell et al. 2016; Fondong et al. 2016; Fondong 2017). For CBSD, siRNA-based approaches against CBSV and UCBSV, individually, have been shown under greenhouse and field conditions (Yadav et al. 2011; Ogwok et al. 2012; Vanderschuren et al. 2012; Odipio et al 2014). These efforts used hpRNA encoding coat protein (CP) sequences from CBSV or UCBSV singly. More recently, both viruses have been targeted within the same plant by using hpRNA composed of CP sequences from both viruses fused in tandem within one gene construct. Robust resistance to CBSD in these transgenic cassava plants has been shown in multilocation field trials over successive vegetative cropping cycles within high disease locations in East Africa (Wagaba et al. 2016a; Wagaba and Taylor 2018). A strong positive correlation was shown for levels of CBSD resistance and accumulation of siRNAs derived from the RNAi construct (Beyene et al. 2017). A product development program continues for this technology, with lead plant lines undergoing assessment within regulatory field trials in Kenya and Uganda. In addition, an miRNA approach for CBSD control has been shown in Nicotiana benthamiana, an alternative host for CBSV (Wagaba et al. 2016b).

PDR has also been used to address CMD. By constitutively expressing a mutated $A C 1$ gene from African cassava mosaic virus (ACMV), Chellepan and colleagues were able to generate resistance to ACMV and the related species East African cassava mosaic virus (EACMV) and Sri Lankan cassava mosaic virus (SLCMV) under greenhouse conditions (Chellappan et al. 2004). Although not an hpRNA strategy per se, evidence for production of siRNAs from the transgenic sequence indicated that posttranscriptional gene silencing had been triggered in these plants. Subsequent studies expressing AC1 sequences from hpRNA constructs in transgenic 
cassava plants also report robust resistance to infection with the homologous virus (Vanderschuren et al. 2009; Ntui et al. 2015). Subsequent field trials to assess efficacy of $A C 1$-derived hairpin RNAi approaches for resistance to CMD have taken place in Nigeria and Uganda with significant resistance to EACMV achieved in East Africa (unpubl.). Farmer products have not developed from these initial field trials. Indeed, efforts to engineer resistance to CMD have not been aggressively pursued over the last decade owing to the successful deployment of conventionally bred varieties with high levels of resistance to $\mathrm{CMD}$, and the increased importance of CBSD in sub-Saharan Africa. The emergence of CMD in Asia, where large areas are planted to a single variety such as KU50, may once again provide opportunity and need for development of engineered resistance to CMD.

An interesting phenomenon associated with efforts to develop transgenic cassava was reported by Beyene et al. (2016) and Chauhan et al. (2018), in which plants carrying the CMD2-type resistance became highly susceptible to CMD. Loss of resistance to CMD was found to occur during production of the morphogenic tissues used for transgene integration and not to result from expression of siRNAs or other transgenes. Efforts to exploit this knowledge to understand and utilize CMD2 resistance to CMD are more fully described below.

\section{Gene-Editing Approaches to Cassava Diseases}

A common aspect in plant-pathogen interactions is the use of virulence factors by pathogens to subvert host immune responses and co-opt host processes for successful completion of the pathogen life cycle (Mandadi and Scholthof 2013; Toruño et al. 2016). Pathogens may occasionally depend on a singular host-encoded susceptibility gene, or perhaps a small gene family, for progression of disease. An example is the interaction between potyvirid VPg and members of the plant eIF4E family of translation initiation factors (Robaglia and Caranta 2006; Bastet et al. 2017). This interaction is conserved in many potyvirid plant pathosystems and is essential for successful virus infection (Robaglia and Caranta 2006; Revers and García 2015). Natural or artificial mutants in susceptibility genes have been used extensively as sources of resistance but can be difficult to identify or generate (Dangl et al. 2013; Revers and Nicaise 2014). The advent of CRISPR/Cas-mediated gene editing accelerates this process, allowing the transfer of strategies from model plants and genetically tractable crops to orphan crops like cassava (Belhaj et al. 2015; Langner et al. 2018). The most heavily used CRISPR/Cas technology uses Cas nucleases guided by RNA molecules (guide RNAs [gRNAs]) to complementary DNA. In the eukaryotic cell, the Cas nuclease will create a double-stranded break (DSB) at the targeted DNA locus. The DSB is frequently repaired through error-prone nonhomologous end joining (NHEJ), often resulting in insertions or deletions at the repaired locus. By transforming a plant with a construct encoding a Cas nuclease and gRNAs specific for susceptibility genes, the encoded susceptibility factors can be mutated to engineer resistance against certain pathogens (Wang et al. 2014).

CRISPR/Cas editing of susceptibility factors has been demonstrated in Arabidopsis and cucumber, where eIF4E family genes necessary for potyvirus virulence, but dispensible for normal growth and development, were mutated, resulting in resistant plants (Chandrasekaran et al. 2016; Pyott et al. 2016). In cassava, this strategy has been implemented against CBSD. Cassava encodes five eIF4E family genes: one of eIF4E, two $\operatorname{IF}$ (iso) $4 E$ paralogs, and two $n C B P$ paralogs. VPg protein of CBSV-Naliendele isolate TZ: Nal3-1:07 was found to consistently associate with both cassava nCBPs in yeast two-hybrid and co-immunoprecipitation experiments (Gomez et al. 2019). Null ncbp double mutants were then generated through CRISPR/Cas editing and graft inoculated with CBSV-Naliendele in greenhouse trials. The $n c b p$ double mutants were delayed in CBSD aerial symptom development across all experiments and end point root symptom severity was greatly reduced, correlating with mean reductions in storage-root virus titer of $43 \%-45 \%$ (Gomez et al. 2019). The ability of CBSV to still accumulate in $n c b p$ double mutants is possibly because of redundancy in 
Z.J.D. Lin et al.

the cassava eIF4E family of genes. This is supported by CBSV-Naliendele VPg co-immunoprecipitating with not only cassava nCBPs, but also all other cassava eIF4E family proteins (Gomez et al. 2019). It is unclear to what degree cassava eIF4E and eIF(iso)4E proteins contribute to CBSD, but partial resistance observed in the $n c b p$ double-mutant background suggests that CBSV cannot use all eIF4E family proteins equally well for virulence. Once the full complement of eIF4E family susceptibility factors used by CBSV and UCBSV is characterized, targeted gene editing can again be tested as a potential strategy for CBSD control.

$\mathrm{CBB}$ is another disease that may be controlled using CRISPR/Cas editing, as pathogenic Xanthomonads secrete TAL effector proteins into host cells to up-regulate expression of susceptibility factors. In particular, the Xam TAL20 effector was found to bind the promoter of cassava MeSWEET10a and activate its expression (Cohn et al. 2014). When TAL20 is absent, Xam proliferation and associated water soaking symptoms are reduced. The TAL20-binding site is then a potential target for gene editing to engineer cassava resistance against Xam. A similar strategy was successfully deployed in rice and citrus and may be appropriate for other Xanthomonad-incited diseases ( $\mathrm{Li}$ et al. 2012; Cox et al. 2017; Jia et al. 2017; Phillips et al. 2017).

In contrast to $\mathrm{CBSD}$ and $\mathrm{CBB}, \mathrm{CMD}$ has no known susceptibility genes that can be targeted by gene editing. However, as CMGs are DNA viruses, the viral genomes themselves can be targeted by CRISPR/Cas. This has been successfully shown against various geminiviruses in N. benthamiana and Arabidopsis thaliana (Ali et al. 2015, 2016; Baltes et al. 2015; Ji et al. 2015). In these systems, viral load and symptom severity could be drastically reduced through CRISPR/Cas-mediated interference and evidence of viral genome editing was generally observed (Ali et al. 2015, 2016; Baltes et al. 2015; Ji et al. 2015). A number of effective antiviral gRNAs used in these studies targeted geminiviral coding regions. NHEJ-mediated repair could theoretically result in missense or amino acid insertion/deletion events that allow for produc- tion of functional viral protein, in addition to mutating the gRNA target site so that Cas binding is no longer possible; this would generate viruses resistant to CRISPR/Cas interference. This is supported by the Ali et al. study in which CRISPR/Cas-interference-resistant virus was isolated from infected plants expressing Cas nuclease and gRNA that targeted geminiviral CP gene (Ali et al. 2015, 2016). Similarly, Mehta and colleagues found that a small proportion of viruses isolated from cassava expressing Cas and a gRNA targeting cassava mosaic virus $A C 2$ and $A C 3$ genes had become editing-resistant (Mehta et al. 2019). Furthermore, these editing-resistant viruses were predicted to produce truncated AC2 and $\mathrm{AC} 3$ proteins that could potentially be functional. In addition to targeting coding sequences, Ali and colleagues found that targeting a highly conserved nonanucleotide noncoding motif in the geminiviral long intergenic region (LIR), critical for geminiviral replication, was also effective at attenuating geminiviral accumulation (Ali et al. 2016). Targeting these critical noncoding sequences may be preferable if their function is less tolerant of mutations as compared with coding sequences. Furthermore, multiplexing gRNAs to target multiple geminiviral genomic loci simultaneously provided for stronger resistance than only targeting one locus (Ali et al. 2015; Baltes et al. 2015). These findings suggest that future use of CRISPR/Cas-mediated interference against geminiviruses should use simultaneous LIR and coding sequence targeting with multiple gRNAs for effective disease control that does not facilitate the evolution of editing-resistant viruses.

Engineering Synthetic Resistance Alleles of Susceptibility Factors

Knocking out host susceptibility genes is a simple way of depriving pathogens of necessary tools for carrying out their life cycles. However, this strategy is not always possible as certain susceptibility factors are essential for host viability. This is exemplified in cases in which engineering broad spectrum potyvirus resistance requires knocking out multiple eIF4E family members as certain $e I F 4 E$ family mutant com- 
binations are nonviable (Bastet et al. 2017). Recently, a novel approach was developed to address this issue. In some potyvirus-plant pathosystems, much is known regarding the amino acid residues involved in VPg-eIF4E interaction (Wang and Krishnaswamy 2012; Bastet et al. 2017). Bastet et al. $(2018,2019)$ used this knowledge to generate Arabidopsis eIF4E1 variants that do not associate with VPg of multiple potyviruses (eIF4E1 ${ }^{\mathrm{R}}$ ), and then replaced eIF4E1 with eIF4E $1^{R}$ in an eif(iso) 4 e mutant. eif(iso) $4 e$ confers resistance to a separate set of potyviruses than $e I F 4 E 1^{R}$, and both $e I F 4 E 1$ and $e I F($ iso $) 4 E$ are needed simultaneously for viability (Bastet et al. 2017). Bastet and colleagues were also able to use a CRISPR approach in which a modified Cas nickase-cytidine deaminase fusion targeted to eIF4E1 generated the necessary missense mutation to produce an eIF4E1 synthetic resistance allele (Bastet et al. 2019). This strategy differs from standard Cas nuclease targeting as cytosines at the targeted region are either directly converted to thymine by cytidine deaminase or are converted to guanine or adenine by error-prone repair. Applying these principles to CBSD should be possible if U/CBSV VPg and cassava eIF4E family interaction domains can be identified. Additionally, this strategy can potentially also be applied to CMD as numerous geminiviral-host protein interactions are known (Hanley-Bowdoin et al. 2013; Castillo-González et al. 2015).

\section{Exploiting Native Resistance Mechanisms} to Engineer Disease Resistance

Varying levels of resistance and tolerance to the major diseases affecting cassava exist within the many hundreds of cultivars grown across the tropics. Wild relatives of the crop also provide opportunity for integrating disease resistance into cultivated cassava. Insufficient knowledge of the genes and resistance mechanisms imparting disease resistance presently constrain efforts to exploit these resources. However, increasing quality of genomic platforms and capacity for engineering in cassava is changing this scenario (Wang et al. 2015; Bredeson et al. 2016; Chavarriaga-Aguirre et al. 2016; Wilson et al. 2017). An early example is efforts to understand CMD2. CMD2 provides resistance to CMD imparted in a dominant manner by a single locus or single gene located on chromosome 12 (Akano et al. 2002). Loss-of-functional CMD2 by passage through in vitro morphogenesis provides unprecedented opportunity to identify the specific gene(s) responsible for $C M D 2$-imparted resistance to geminiviruses (Beyene et al. 2016). One hypothesis is that loss of activity is the result of in vitro morphogenesis-induced differential methylation of regulatory DNA associated with $C M D 2$. Once understood, application, as appropriate, of conventional transgenic approaches, gene-editing technology or engineered methylation of the CMD2 sequence offers potential to enhance its function and/or transfer $C M D 2$ into presently susceptible varieties. It is considered that such approaches will become increasingly important for future engineering of disease resistance in cassava and other crops.

\section{Immune Receptor Transfer}

The plant immune system provides robust defense against microbial pathogens contingent on pathogen perception. Immune responses are initiated by two classes of immune receptors: pattern recognition receptors (PRRs) at the plasma membrane, and intracellular nucleotidebinding domain leucine-rich repeat receptors (NLRs, also known as Nod-like receptors) (Cook et al. 2015). PRRs are typically membrane localized receptor-like kinases or receptor-like proteins (RLPs) that perceive conserved molecular patterns of extracellular pathogens. These patterns can be broadly conserved within classes of pathogens, or more narrowly across genera and species (Ranf 2018). Immunity triggered through this mode is called pattern-triggered immunity (PTI). Nearly all pathogen classes have evolved to secrete effector proteins into host cells that directly interfere with multiple levels of the PTI signaling cascade, via many biochemical modes of action (Toruño et al. 2016). In turn, intracellular NLRs are able to recognize the presence of effectors either through direct NLR-effector interaction or by monitoring for effectormediated biochemical perturbations made to 
Z.J.D. Lin et al.

host proteins. NLR activation then results in effector-triggered immunity (ETI) (Thomma et al. 2011; Cook et al. 2015; Cui et al. 2015).

The relatively broad spectrum of resistance afforded by PRRs makes PRR transfer between plant species a particularly attractive disease control strategy. Intra- and interfamily PRR transfer has been demonstrated in numerous instances, as well as between monocots and dicots, underscoring a conservation of signaling pathways downstream from PRR-ligand binding events (Holton et al. 2015; Boutrot and Zipfel 2017; Rodriguez-Moreno et al. 2017; Ranf 2018). In cassava, the main use of PRR transfer would be for engineering resistance against extracellular pathogens like fungi, oomycetes, and bacteria. In particular, PRRs that recognize Xanthomonads have been identified and could be of use against CBB. Xa21, an RLK-type PRR from rice, perceives the sulfonated RaxX protein from Xanthomonads, and RaxX as well as the enzyme responsible for its sulfonation are found in at least one Xam strain (da Silva et al. 2004; Pruitt et al. 2015). The elongation factor receptor (EFR) is a PRR from Brassicacea that perceives bacterial elongation factor $\mathrm{Tu}(\mathrm{EF}-\mathrm{Tu})$; EF-Tu is highly conserved among all bacteria and transfer of Arabidopsis EFR to tomato confers immune responsiveness to Xanthomonas perforans (Lacombe et al. 2010). Another PRR, the RLP ReMAX from Arabidopsis, can initiate immune responses when exposed to Xanthomonas axonopodis pv. citri extract; this extract contains a suspected proteinaceous ligand, eMax, which is yet to be identified (Jehle et al. 2013). Interestingly, the widely conserved PRR FLS2 has slightly varying specificities and sensitivities between species, and interspecific transfer can confer recognition of additional pathogens (Chinchilla et al. 2006; Sun et al. 2006; Hao et al. 2016). There is good evidence that many of these receptors will be readily functional after transfer into cassava, whereas a subset may require additional engineering (Mendes et al. 2010; Afroz et al. 2011; Jehle et al. 2013; Tripathi et al. 2014; Holton et al. 2015).

NLR transfer to confer resistance to $\mathrm{CBB}$ and CBSD is also a possibility as a number of NLRs that recognize Xanthomonads and poty- viruses have been identified (de Ronde et al. 2014; Kapos et al. 2019). In some instances, NLR transfer may be even more useful than PRR deployment as certain adapted pathogens can disrupt PRR signaling cascades (Toruño et al. 2016). However, in contrast to PRRs, interspecific transfer of NLRs has rarely been successful, likely caused by the diverse mechanisms of NLR activation (Toruño et al. 2016; RodriguezMoreno et al. 2017). Some NLRs perceive effectors through direct association, but many characterized NLRs are activated when an effector exerts its enzymatic activity on an NLR-associated host protein (Monteiro and Nishimura 2018). This host protein can be the actual effector target or a homologous protein and is then described as either a guardee or decoy, respectively, and must be present for proper NLR activity. Of the five known NLRs that confer resistance to Xanthomonads, all have unknown modes of effector recognition (Kapos et al. 2019). One of these, Roq1 from Nicotiana, directly associates with its cognate effector avrRoq1 (conserved in many Xam strains), but it is not clear whether this is sufficient for Roq1 activation (Schultink et al. 2017). There are also a handful of NLRs known to confer resistance to potyviruses, but their cognate viral proteins or modes of recognition are unknown (de Ronde et al. 2014). Further complicating matters is the revelation that NLRs directly involved in effector perception, "sensor" NLRs, may also require the presence of additional "helper" NLRs (Rodriguez-Moreno et al. 2017; Białas et al. 2018). These helper NLRs can be either genetically linked or unlinked with the sensor NLR and their necessity may be difficult to predict a priori. Given this current understanding of NLR biology, successful NLR transfer to cassava for $\mathrm{CBB}$ and $\mathrm{CBSD}$ resistance will likely require significant effort.

\section{Engineering New Immune Receptor Specificity}

Despite predicted difficulties in using NLRs for potyvirid resistance, it is worth noting that an NLR that recognizes the bacterial pathogen Pseudomonas syringae has been co-opted for 
potyvirus resistance. The particular NLR, RPS5 of Arabidopsis, is activated on proteolytic cleavage of the PBS1 kinase by the P. syringae effector AvrPphB (Shao et al. 2003; Qi et al. 2014). When the AvrPphB cleavage site within PBS1 was replaced with the cleavage site of Turnip mosaic virus (TuMV) NIa protease, RPS5 was able to drive an immune response against TuMV (Kim et al. 2016). Similar results were observed by modifying the soybean PBS1 homolog to be cleaved by NIa of soybean mosaic virus (Helm et al. 2019). NIa cleavage sites of different potyvirids are easily identifiable, and this artificial mechanism of potyviral resistance should be readily transferable to any plant species with $P B S 1$, including cassava, as long as a suitable NLR is also present for perceiving PBS1 cleavage (Adams et al. 2005). CBSVs are an obvious target for this strategy, which could also be applied toward any cassava pathogen that secretes protease-type effectors with known cleavage sites. In the future, perhaps NLR surveillance systems that can detect other biochemical activities, such as phosphorylation or ADP-ribosylation, can also be engineered to expand the scope of effectors that can be recognized.

\section{A PROMISING FUTURE FOR ENGINEERING DISEASE-RESISTANT PLANTS}

Many mechanisms underpinning gene regulation and the plant immune system have become better understood in recent years. These developments are accompanied with novel biotechnological strategies and enable accelerated engineering of resistance against diseases that in the past would have required laborious germplasm screening and breeding efforts. The strategies discussed in this review are extremely promising for deploying resistance to $\mathrm{CMD}$, CBSD, and CBB, but also may be applied to newly emerging cassava diseases. For example, plants have recently been found to secrete sRNAs in extracellular vesicles that can then be taken up by fungal pathogens, resulting in cross-kingdom RNAi and subsequent silencing of fungal pathogenicity genes (Cai et al. 2018). Such an approach could be applied to cassava anthracnose. Alternatively, susceptibility factor editing and engineering is broadly applicable as effector-mediated modulation of host processes is universal among all pathogen classes. PTI and ETI have also been shown to be effective against insects, indicating that cassava may even be engineered to be resistant to the CMD and CBSD whitefly vector (Douglas 2018; Erb and Reymond 2019). The successful translation of these approaches will undoubtedly require much work as many questions still exist about underlying principles, but the future of engineering disease-resistant plants is particularly bright.

Multiple strategies are described above for engineering disease resistance in cassava. In a few cases, performance has been shown at the field level and, in the example of RNAi-imparted resistance to CBSD, is being pursued within a product development program to seek regulatory approval and deployment to farmers in Kenya and Uganda (Wagaba et al. 2016a). Other strategies remain unproven in cassava. All such research efforts are valid. However, focus must also remain on the goal of such investments, which is to improve livelihoods and opportunities for cassava farmers, processors, and consumers in the tropics. Many of the strategies described require a transgenic approach. In such cases, a significant program of field performance, food feed, and environmental assessment must be performed to comply with regulatory requirements in each country where deployment is sought. Dossiers are compiled and submitted for review to seek approval by regulatory authorities in each country. If successful, national performance trials are required before variety registration and release to farmers. This multiyear process presents challenges and is complicated by the fact that many cassavaproducing countries do not have functional regulatory or legal structures in place to facilitate development and approval of transgenic crops. In some cases, important progress is being made, for example, in Nigeria, the world's largest cassava-producing country, which recently approved Bt cowpea for cultivation by farmers. In other countries, inclusion of restrictive language in their biosafety laws effectively prevent deployment of transgenic crops, ensuring that their farmers cannot benefit from cassava or other 
Z.J.D. Lin et al.

crops enhanced through the use of biotechnology. Of concern is how cassava-producing countries will regulate the products of gene-editing technologies. It is critically important that they do not follow the path of GMOs but instead seek processes that will allow cassava farmers to benefit from the important opportunities to develop disease resistance described above.

\section{REFERENCES}

Adams MJ, Antoniw JF, Beaudoin F. 2005. Overview and analysis of the polyprotein cleavage sites in the family Potyviridae. Mol Plant Pathol 6: 471-487. doi:10.1111/j .1364-3703.2005.00296.x

Afroz A, Chaudhry Z, Rashid U, Ali GM, Nazir F, Iqbal J, Khan MR. 2011. Enhanced resistance against bacterial wilt in transgenic tomato (Lycopersicon esculentum) lines expressing the Xa21 gene. Plant Cell Tissue Organ Cult 104: 227-237. doi:10.1007/s11240-010-9825-2

Akano O, Dixon O, Mba C, Barrera E, Fregene M. 2002. Genetic mapping of a dominant gene conferring resistance to cassava mosaic disease. Theor Appl Genet 105: 521-525. doi:10.1007/s00122-002-0891-7

Ali Z, Abul-faraj A, Li L, Ghosh N, Piatek M, Mahjoub A, Aouida M, Piatek A, Baltes NJ, Voytas DF, et al. 2015 Efficient virus-mediated genome editing in plants using the CRISPR/Cas9 system. Mol Plant 8: 1288-1291. doi:10 .1016/j.molp.2015.02.011

Ali Z, Ali S, Tashkandi M, Zaidi SSEA, Mahfouz MM. 2016 CRISPR/Cas9-mediated immunity to geminiviruses: Differential interference and evasion. Sci Rep 6: 26912. doi:10 $.1038 /$ srep26912

Alvarez E, Mejía JF, Llano GA, Loke JB, Calari A, Duduk B, Bertaccini A. 2009. Characterization of a phytoplasma associated with frogskin disease in cassava. Plant Dis 93: 1139-1145. doi:10.1094/PDIS-93-11-1139

Alvarez E, Pardo JM, Mejia JF, Bertaccini A, Thanh ND, Hoat TX. 2013. Detection and identification of "Candidatus Phytoplasma asteris"-related phytoplasmas associated with a witches' broom disease of cassava in Vietnam. Phytopathogenic Mollicutes 3: 77. doi:10.5958/j.22494677.3.2.018

Arocha Y, Echodu R, Talengera D, Muhangi J, Rockefeller E, Asher O, Nakacwa R, Serugga R, Gumisiriza G, Tripathi J, et al. 2009. Occurrence of "Candidatus Phytoplasma aurantifolia” (16SrII group) in cassava and four other species in Uganda. Plant Pathol 58: 390-390. doi:10.1111/j.13653059.2008.01963.x

Baltes NJ, Hummel AW, Konecna E, Cegan R, Bruns AN, Bisaro DM, Voytas DF. 2015. Conferring resistance to geminiviruses with the CRISPR-Cas prokaryotic immune system. Nat Plants 1: 15145. doi:10.1038/nplants .2015 .145

Banito A, Kpemoua KE, Wydra K. 2008. Expression of resistance and tolerance of cassava genotypes to bacterial blight determined by genotype $\mathrm{x}$ environment interactions. J Plant Dis Prot 115: 152-161. doi:10.1007/ BF03356261
Bart R, Cohn M, Kassen A, McCallum EJ, Shybut M, Petriello A, Krasileva K, Dahlbeck D, Medina C, Alicai T, et al. 2012. High-throughput genomic sequencing of cassava bacterial blight strains identifies conserved effectors to target for durable resistance. Proc Natl Acad Sci 109: E1972-E1979. doi:10.1073/pnas.1208003109

Bastet A, Robaglia C, Gallois JL. 2017. eIF4E resistance: Natural variation should guide gene editing. Trends Plant Sci 22: 411-419. doi:10.1016/j.tplants.2017.01.008

Bastet A, Lederer B, Giovinazzo N, Arnoux X, GermanRetana S, Reinbold C, Brault V, Garcia D, Djennane S, Gersch S, et al. 2018. Trans-species synthetic gene design allows resistance pyramiding and broad-spectrum engineering of virus resistance in plants. Plant Biotechnol J 16: 1569-1581. doi:10.1111/pbi.12896

Bastet A, Zafirov D, Giovinazzo N, Guyon-Debast A, Nogué F, Robaglia C, Gallois JL. 2019. Mimicking natural polymorphism in eIF4E by CRISPR-Cas9 base editing is associated with resistance to potyviruses. Plant Biotechnol $)$ doi:10.1111/pbi.13096

Belhaj K, Chaparro-Garcia A, Kamoun S, Patron NJ, Nekrasov V. 2015. Editing plant genomes with CRISPR/Cas9. Curr Opin Biotechnol 32: 76-84. doi:10.1016/j.copbio .2014.11.007

Beyene G, Chauhan RD, Wagaba H, Moll T, Alicai T, Miano D, Carrington JC, Taylor NJ. 2016. Loss of CMD2-mediated resistance to cassava mosaic disease in plants regenerated through somatic embryogenesis. Mol Plant Pathol 17: 1095-1110. doi:10.1111/mpp.12353

Beyene G, Chauhan RD, Ilyas M, Wagaba H, Fauquet CM, Miano D, Alicai T, Taylor NJ. 2017. A virus-derived stacked RNAi construct confers robust resistance to cassava brown streak disease. Front Plant Sci 7: 2052. doi:10 .3389/fpls.2016.02052

Białas A, Zess EK, De la Concepcion JC, Franceschetti M, Pennington HG, Yoshida K, Upson JL, Chanclud E, Wu CH, Langner T, et al. 2018. Lessons in effector and NLR biology of plant-microbe systems. Mol Plant Microbe Interact 31: 34-45. doi:10.1094/MPMI-08-17-0196-FI

Borges F, Martienssen RA. 2015. The expanding world of small RNAs in plants. Nat Rev Mol Cell Biol 16: 727-741. doi:10.1038/nrm4085

Boutrot F, Zipfel C. 2017. Function, discovery, and exploitation of plant pattern recognition receptors for broadspectrum disease resistance. Annu Rev Phytopathol 55 257-286. doi:10.1146/annurev-phyto-080614-120106

Bredeson JV, Lyons JB, Prochnik SE, Wu GA, Ha CM, Edsinger-Gonzales E, Grimwood J, Schmutz J, Rabbi IY, Egesi C, et al. 2016. Sequencing wild and cultivated cassava and related species reveals extensive interspecific hybridization and genetic diversity. Nat Biotechnol 34: 562570. doi: $10.1038 /$ nbt.3535

Cai Q, Qiao L, Wang M, He B, Lin FM, Palmquist J, Huang SD, Jin H. 2018. Plants send small RNAs in extracellular vesicles to fungal pathogen to silence virulence genes. Science 360: 1126-1129. doi:10.1126/science.aar4142

Carbonell A, Carrington JC, Daròs JA. 2016. Fast-forward generation of effective artificial small RNAs for enhanced antiviral defense in plants. RNA Dis 3: e1130. doi:10 $.14800 / \mathrm{rd} .1130$

Castillo-González C, Liu X, Huang C, Zhao C, Ma Z, Hu T, Sun F, Zhou Y, Zhou X, Wang XJ, et al. 2015. Geminivi- 
rus-encoded TrAP suppressor inhibits the histone methyltransferase SUVH4/KYP to counter host defense. eLife 4: e06671. doi:10.7554/eLife.06671

Chandrasekaran J, Brumin M, Wolf D, Leibman D, Klap C, Pearlsman M, Sherman A, Arazi T, Gal-On A. 2016. Development of broad virus resistance in non-transgenic cucumber using CRISPR/Cas9 technology. Mol Plant Pathol 17: 1140-1153. doi:10.1111/mpp.12375

Chauhan RD, Beyene G, Taylor NJ. 2018. Multiple morphogenic culture systems cause loss of resistance to cassava mosaic disease. BMC Plant Biol 18: 132. doi:10.1186/ s12870-018-1354-x

Chavarriaga-Aguirre P, Brand A, Medina A, Prías M, Escobar R, Martinez J, Díaz P, López C, Roca WM, Tohme J. 2016. The potential of using biotechnology to improve cassava: A review. In Vitro Cell Dev Biol Plant 52: 461478. doi:10.1007/s11627-016-9776-3

Chellappan P, Vanitharani R, Pita J, Fauquet CM. 2004 Short interfering RNA accumulation correlates with host recovery in DNA virus-infected hosts, and gene silencing targets specific viral sequences. J Virol 78: 74657477. doi:10.1128/JVI.78.14.7465-7477.2004

Chinchilla D, Bauer Z, Regenass M, Boller T, Felix G. 2006. The Arabidopsis receptor kinase FLS2 binds flg22 and determines the specificity of flagellin perception. Plant Cell 18: 465-476. doi:10.1105/tpc.105.036574

Cohn M, Bart RS, Shybut M, Dahlbeck D, Gomez M, Morbitzer R, Hou B-H, Frommer WB, Lahaye T, Staskawicz BJ. 2014. Xanthomonas axonopodis virulence is promoted by a transcription activator-like effector-mediated induction of a SWEET sugar transporter in cassava. Mol Plant Microbe Interact 27: 1186-1198. doi:10.1094/MPMI-0614-0161-R

Cohn M, Morbitzer R, Lahaye T, Staskawicz BJ. 2016. Comparison of gene activation by two TAL effectors from Xanthomonas axonopodis pv. manihotis reveals candidate host susceptibility genes in cassava. Mol Plant Patho 17: 875-889. doi:10.1111/mpp.12337

Cook DE, Mesarich CH, Thomma BPHJ. 2015. Understanding plant immunity as a surveillance system to detect invasion. Annu Rev Phytopathol 53: 541-563. doi:10 .1146/annurev-phyto-080614-120114

Cox KL, Meng F, Wilkins KE, Li F, Wang P, Booher NJ, Carpenter SCD, Chen L-Q, Zheng H, Gao X, et al. 2017. TAL effector driven induction of a SWEET gene confers susceptibility to bacterial blight of cotton. Nat Commun 8: 15588. doi:10.1038/ncomms 15588

Cui H, Tsuda K, Parker JE. 2015. Effector-triggered immunity: From pathogen perception to robust defense. Annu Rev Plant Biol 66: 487-511. doi:10.1146/annurev-ar plant-050213-040012

Dangl JL, Horvath DM, Staskawicz BJ. 2013. Pivoting the plant immune system from dissection to deployment. Science 341: 746-751. doi:10.1126/science.1236011

da Silva FG, Shen Y, Dardick C, Burdman S, Yadav RC, de Leon AL, Ronald PC. 2004. Bacterial genes involved in type I secretion and sulfation are required to elicit the rice Xa21-mediated innate immune response. Mol Plant Microbe Interact 17: 593-601. doi:10.1094/MPMI.2004.17.6 .593 de Ronde D, Butterbach P, Kormelink R. 2014. Dominant resistance against plant viruses. Front Plant Sci 5: 307. doi:10.3389/fpls.2014.00307

Douglas AE. 2018. Strategies for enhanced crop resistance to insect pests. Annu Rev Plant Biol 69: 637-660. doi:10 .1146/annurev-arplant-042817-040248

Erb M, Reymond P. 2019. Molecular interactions between plants and insect herbivores. Annu Rev Plant Biol 70: 527-557. doi:10.1146/annurev-arplant-050718-095910

Fanou AA, Zinsou AV, Wydra K. 2017. Survival of Xanthomonas axonopodis pv. manihotis in weed species and in cassava debris: Implication in the epidemiology of cassava bacterial blight. IJAR 5: 2098-2112. doi:10.5772/inte chopen.71527

Fanou AA, Zinsou VA, Wydra K. 2018. Cassava bacterial blight: A devastating disease of cassava. In Cassava (ed. Waisundara V). InTechOpen, London. doi:10.5772/inte chopen.71527

Flôres D, Haas IC, Canale MC, Bedendo IP. 2013. Molecular identification of a 16SrIII-B phytoplasma associated with cassava witches' broom disease. Eur J Plant Pathol 137: 237-242. doi:10.1007/s10658-013-0250-3

Fondong VN. 2017. The search for resistance to cassava mosaic geminiviruses: How much we have accomplished, and what lies ahead. Front Plant Sci 8: 408. doi:10.3389/ fpls.2017.00408

Fondong VN, Nagalakshmi U, Dinesh-Kumar SP. 2016. Novel functional genomics approaches: A promising future in the combat against plant viruses. Phytopathology 106: 1231-1239. doi:10.1094/PHYTO-03-16-0145-FI

Food and Agriculture Organization of the United Nations. 2013. Save and grow: Cassava: A guide to sustainable production intensification. FAO, Rome, Italy.

Gomez MA, Lin ZD, Moll T, Chauhan RD, Hayden L, Renninger K, Beyene G, Taylor NJ, Carrington JC, Staskawicz BJ, et al. 2019. Simultaneous CRISPR/Cas9-mediated editing of cassava eIF4E isoforms $n C B P-1$ and $n C B P-2$ reduces cassava brown streak disease symptom severity and incidence. Plant Biotechnol J 17: 421-434. doi:10.1111/ pbi. 12987

Hanley-Bowdoin L, Bejarano ER, Robertson D, Mansoor S. 2013. Geminiviruses: Masters at redirecting and reprogramming plant processes. Nat Rev Microbiol 11: 777788. doi:10.1038/nrmicro3117

Hao G, Pitino M, Duan Y, Stover E. 2016. Reduced susceptibility to Xanthomonas citri in transgenic citrus expressing the FLS2 receptor from Nicotiana benthamiana. Mol Plant Microbe Interact 29: 132-142. doi:10.1094/MPMI09-15-0211-R

Helm M, Qi M, Sarkar S, Yu H, Whitham SA, Innes RW. 2019. Engineering a decoy substrate in soybean to enable recognition of the soybean mosaic virus NIa protease. Mol Plant Microbe Interact doi:10.1094/MPMI-12-180324-R

Hillocks RJ, Wydra K. 2002. Bacterial, fungal and nematode diseases. In Cassava: Biology, production and utilization (ed. Hillocks RJ, Thresh JM, Bellotti AC), pp. 261-280. CABI, Wallingford, UK. doi:10.1079/9780851995243.0 261

Hillocks RJ, Raya MD, Mtunda K, Kiozia H. 2001. Effects of brown streak virus disease on yield and quality of cassava 
Z.J.D. Lin et al.

in Tanzania. J Phytopathol 149: 389-394. doi:10.1046/j 1439-0434.2001.00641.x

Hogenhout SA, Oshima K, Ammar ED, Kakizawa S, Kingdom HN, Namba S. 2008. Phytoplasmas: Bacteria that manipulate plants and insects. Mol Plant Pathol 9: 403423. doi:10.1111/j.1364-3703.2008.00472.x

Holton N, Nekrasov V, Ronald PC, Zipfel C. 2015. The phylogenetically-related pattern recognition receptors EFR and XA21 recruit similar immune signaling components in monocots and dicots. PLoS Pathog 11: e1004602. doi:10.1371/journal.ppat.1004602

Jehle AK, Fürst U, Lipschis M, Albert M, Felix G. 2013 Perception of the novel MAMP eMax from different Xanthomonas species requires the Arabidopsis receptor-like protein ReMAX and the receptor kinase SOBIR. Plant Signal Behav 8: e27408. doi:10.4161/psb.27408

Ji X, Zhang H, Zhang Y, Wang Y, Gao C. 2015. Establishing a CRISPR-Cas-like immune system conferring DNA virus resistance in plants. Nat Plants 1: 15144. doi:10.1038/ nplants.2015.144

Jia H, Zhang Y, Orbović V, Xu J, White FF, Jones JB, Wang N. 2017. Genome editing of the disease susceptibility gene CsLOB1 in citrus confers resistance to citrus canker. Plant Biotechnol J 15: 817-823. doi:10.1111/pbi.12677

Kapos P, Devendrakumar KT, Li X. 2019. Plant NLRs: From discovery to application. Plant Sci 279: 3-18. doi:10.1016/ j.plantsci.2018.03.010

Kim SH, Qi D, Ashfield T, Helm M, Innes RW. 2016. Using decoys to expand the recognition specificity of a plant disease resistance protein. Science 351: 684-687. doi:10 $.1126 /$ science.aad3436

Lacombe S, Rougon-Cardoso A, Sherwood E, Peeters N, Dahlbeck D, van Esse HP, Smoker M, Rallapalli G, Thomma BPHJ, Staskawicz B, et al. 2010. Interfamily transfer of a plant pattern-recognition receptor confers broad-spectrum bacterial resistance. Nat Biotechnol 28: 365-369. doi:10.1038/nbt.1613

Langner T, Kamoun S, Belhaj K. 2018. CRISPR crops: Plant genome editing toward disease resistance. Annu Rev Phytopathol 56: 479-512. doi:10.1146/annurev-phyto080417-050158

Legg JP, Fauquet CM. 2004. Cassava mosaic geminiviruses in Africa. Plant Mol Biol 56: 585-599. doi:10.1007/s11103004-1651-7

Legg JP, Lava Kumar P, Makeshkumar T, Tripathi L, Ferguson M, Kanju E, Ntawuruhunga P, Cuellar W. 2015. Cassava virus diseases: Biology, epidemiology, and management. Adv Virus Res 91: 85-142. doi:10.1016/bs.aivir .2014 .10 .001

Li T, Liu B, Spalding MH, Weeks DP, Yang B. 2012. Highefficiency TALEN-based gene editing produces diseaseresistant rice. Nat Biotechnol 30: 390-392. doi:10.1038/ nbt.2199

Lindbo JA, Dougherty WG. 1992a. Pathogen-derived resistance to a potyvirus: Immune and resistant phenotypes in transgenic tobacco expressing altered forms of a potyvirus coat protein nucleotide sequence. Mol Plant Microbe Interact 5: 144-153. doi:10.1094/MPMI-5-144

Lindbo JA, Dougherty WG. 1992b. Untranslatable transcripts of the tobacco etch virus coat protein gene sequence can interfere with tobacco etch virus replication in transgenic plants and protoplasts. Virology 189: 725 733. doi:10.1016/0042-6822(92)90595-G

Lindbo JA, Falk BW. 2017. The impact of "coat proteinmediated virus resistance" in applied plant pathology and basic research. Phytopathology 107: 624-634. doi:10 .1094/PHYTO-12-16-0442-RVW

López CE, Bernal AJ. 2012. Cassava bacterial blight: Using genomics for the elucidation and management of an old problem. Trop Plant Biol 5: 117-126. doi:10.1007/s12042011-9092-3

Mandadi KK, Scholthof KBG. 2013. Plant immune responses against viruses: How does a virus cause disease? Plant Cell 25: 1489-1505. doi:10.1105/tpc.113.111658

McCallum EJ, Anjanappa RB, Gruissem W. 2017. Tackling agriculturally relevant diseases in the staple crop cassava (Manihot esculenta). Curr Opin Plant Biol 38: 50-58. doi:10.1016/j.pbi.2017.04.008

Mehta D, Stürchler A, Anjanappa RB, Zaidi SS-e-A, HirschHoffmann M, Gruissem W, Vanderschuren H. 2019. Linking CRISPR-Cas9 interference in cassava to the evolution of editing-resistant geminiviruses. Genome Biol 20: 80. doi:10.1186/s13059-019-1678-3

Mendes BMJ, Cardoso SC, Boscariol-Camargo RL, Cruz RB, Mourão Filho FAA, Bergamin Filho A. 2010. Reduction in susceptibility to Xanthomonas axonopodis pv. citri in transgenic Citrus sinensis expressing the rice Xa21 gene. Plant Pathol 59: 68-75. doi:10.1111/j.1365-3059.2009 .02148.x

Monteiro F, Nishimura MT. 2018. Structural, functional, and genomic diversity of plant NLR proteins: An evolved resource for rational engineering of plant immunity. Annu Rev Phytopathol 56: 243-267. doi:10.1146/annurevphyto-080417-045817

Ntui VO, Kong K, Khan RS, Igawa T, Janavi GJ, Rabindran R, Nakamura I, Mii M. 2015. Resistance to Sri Lankan cassava mosaic virus (SLCMV) in genetically engineered cassava cv. KU50 through RNA silencing. PLoS ONE 10: e0120551. doi:10.1371/journal.pone.0120551

Odipio J, Ogwok E, Taylor NJ, Halsey M, Bua A, Fauquet CM, Alicai T. 2014. RNAi-derived field resistance to cassava brown streak disease persists across the vegetative cropping cycle. GM Crops Food 5: 16-19. doi:10.4161/ gmcr.26408

Ogwok E, Odipio J, Halsey M, Gaitán-Solís E, Bua A, Taylor NJ, Fauquet CM, Alicai T. 2012. Transgenic RNA interference (RNAi)-derived field resistance to cassava brown streak disease. Mol Plant Pathol 13: 1019-1031. doi:10 $.1111 / \mathrm{j} .1364-3703.2012 .00812 . x$

Onyeka TJ, Owolade OF, Ogunjobi AA, Dixon AGO, Okechukwu R, Bandyopadhyay R, Bamkefa B. 2008. Prevalence and severity of bacterial blight and anthracnose diseases of cassava in different agro-ecological zones of Nigeria. Afr J Agric Res 3: 297-304.

Owor B, Legg JP, Okao-Okuja G, Obonyo R, Ogenga-Latigo MW. 2004. The effect of cassava mosaic geminiviruses on symptom severity, growth and root yield of a cassava mosaic virus disease-susceptible cultivar in Uganda. Ann Applied Biol 145: 331-337. doi:10.1111/j.17447348.2004.tb00390.x

Patil BL, Fauquet CM. 2009. Cassava mosaic geminiviruses: Actual knowledge and perspectives. Mol Plant Pathol 10: 685-701. doi:10.1111/j.1364-3703.2009.00559.x 
Patil BL, Legg JP, Kanju E, Fauquet CM. 2015. Cassava brown streak disease: A threat to food security in Africa. J Gen Virol 96: 956-968. doi:10.1099/vir.0.000014

Phillips AZ, Berry JC, Wilson MC, Vijayaraghavan A, Burke J, Bunn JI, Allen TW, Wheeler T, Bart RS. 2017. Genomics-enabled analysis of the emergent disease cotton bacterial blight. PLoS Genet 13: e1007003. doi:10.1371/jour nal.pgen.1007003

Pruitt RN, Schwessinger B, Joe A, Thomas N, Liu F, Albert M, Robinson MR, Chan LJG, Luu DD, Chen H, et al. 2015. The rice immune receptor XA21 recognizes a tyrosine-sulfated protein from a Gram-negative bacterium. Sci Adv 1: e1500245. doi:10.1126/sciadv.1500245

Pyott DE, Sheehan E, Molnar A. 2016. Engineering of CRISPR/Cas9-mediated potyvirus resistance in transgene-free Arabidopsis plants. Mol Plant Pathol 17: 1276-1288. doi:10.1111/mpp.12417

Qi D, Dubiella U, Kim SH, Sloss DI, Dowen RH, Dixon JE, Innes RW. 2014. Recognition of the protein kinase AVRPPHB SUSCEPTIBLE1 by the disease resistance protein RESISTANCE TO PSEUDOMONAS SYRINGAE5 is dependent on $S$-acylation and an exposed loop in AVRPPHB SUSCEPTIBLE1. Plant Physiol 164: 340351. doi:10.1104/pp.113.227686

Ranf S. 2018. Pattern recognition receptors-Versatile genetic tools for engineering broad-spectrum disease resistance in crops. Agronomy 8: 134. doi:10.3390/agrono my8080134

Restrepo S, Vélez CM, Verdier V. 2000. Measuring the genetic diversity of Xanthomonas axonopodis pv. manihotis within different fields in Colombia. Phytopathology 90: 683-690. doi:10.1094/PHYTO.2000.90.7.683

Revers F, García JA. 2015. Molecular biology of potyviruses. Adv Virus Res 92: 101-199. doi:10.1016/bs.aivir.2014.11 .006

Revers F, Nicaise V. 2014. Plant resistance to infection by viruses. eLS doi: 10.1002/9780470015902.a0000757.pub3

Rey C, Vanderschuren H. 2017. Cassava mosaic and brown streak diseases: Current perspectives and beyond. Annu Rev Virol 4: 429-452. doi:10.1146/annurev-virology101416-041913

Robaglia C, Caranta C. 2006. Translation initiation factors: A weak link in plant RNA virus infection. Trends Plant Sci 11: 40-45. doi:10.1016/j.tplants.2005.11.004

Rodamilans B, Valli A, Mingot A, San León D, Baulcombe D, López-Moya JJ, García JA. 2015. RNA polymerase slippage as a mechanism for the production of frameshift gene products in plant viruses of the potyviridae family. J Virol 89: 6965-6967. doi:10.1128/JVI.00337-15

Rodriguez-Moreno L, Song Y, Thomma BP. 2017. Transfer and engineering of immune receptors to improve recognition capacities in crops. Curr Opin Plant Biol 38: 42-49. doi:10.1016/j.pbi.2017.04.010

Rosa C, Kuo Y-W, Wuriyanghan H, Falk BW. 2018. RNA interference mechanisms and applications in plant pathology. Annu Rev Phytopathol 56: 581-610. doi:10 .1146/annurev-phyto-080417-050044

Scholthof K-BG, Adkins S, Czosnek H, Palukaitis P, Jacquot E, Hohn T, Hohn B, Saunders K, Candresse T, Ahlquist P, et al. 2011. Top 10 plant viruses in molecular plant pathology. Mol Plant Pathol 12: 938-954. doi:10.1111/j .1364-3703.2011.00752.x
Schultink A, Qi T, Lee A, Steinbrenner AD, Staskawicz B. 2017. Roq1 mediates recognition of the Xanthomonas and Pseudomonas effector proteins XopQ and HopQ1. Plant J 92: 787-795. doi:10.1111/tpj.13715

Shao F, Golstein C, Ade J, Stoutemyer M, Dixon JE, Innes RW. 2003. Cleavage of Arabidopsis PBS1 by a bacterial type III effector. Science 301: 1230-1233. doi:10.1126/sci ence.1085671

Soto Sedano JC, Mora Moreno RE, Mathew B, Léon J, Gómez Cano FA, Ballvora A, López Carrascal CE. 2017. Major novel QTL for resistance to cassava bacterial blight identified through a multi-environmental analysis. Front Plant Sci 8: 1169. doi:10.3389/fpls.2017.01169

Storey HH. 1936. Virus diseases on East African plants. VI: A progress report on studies of diseases of cassava. East Afr Agric J 2: 34-39.

Sun W, Dunning FM, Pfund C, Weingarten R, Bent AF. 2006. Within-species flagellin polymorphism in Xanthomonas campestris pv campestris and its impact on elicitation of Arabidopsis FLAGELLIN SENSING2-dependent defenses. Plant Cell 18: 764-779. doi:10.1105/tpc.105 .037648

Thomma BPHJ, Nürnberger T, Joosten MHAJ. 2011. Of PAMPs and effectors: The blurred PTI-ETI dichotomy. Plant Cell 23: 4-15. doi:10.1105/tpc.110.082602

Tomlinson KR, Bailey AM, Alicai T, Seal S, Foster GD. 2018 Cassava brown streak disease: Historical timeline, current knowledge and future prospects. Mol Plant Pathol 19: 1282-1294. doi:10.1111/mpp.12613

Toruño TY, Stergiopoulos I, Coaker G. 2016. Plant-pathogen effectors: Cellular probes interfering with plant defenses in spatial and temporal manners. Annu Rev Phytopathol 54: 419-441. doi:10.1146/annurev-phyto-080 615-100204

Tripathi JN, Lorenzen J, Bahar O, Ronald P, Tripathi L. 2014. Transgenic expression of the rice Xa21 pattern-recognition receptor in banana (Musa sp.) confers resistance to Xanthomonas campestris pv. musacearum. Plant Biotechnol J 12: 663-673. doi:10.1111/pbi.12170

Vanderschuren H, Alder A, Zhang P, Gruissem W. 2009. Dose-dependent RNAi-mediated geminivirus resistance in the tropical root crop cassava. Plant Mol Biol 70: 265272. doi:10.1007/s11103-009-9472-3

Vanderschuren H, Moreno I, Anjanappa RB, Zainuddin IM, Gruissem W. 2012. Exploiting the combination of natural and genetically engineered resistance to cassava mosaic and cassava brown streak viruses impacting cassava production in Africa. PLoS ONE 7: e45277. doi:10.1371/jour nal.pone. 0045277

Verdier V, López C, Bernal AJ. 2012. Cassava bacterial blight, caused by Xanthomonas axonopodis pv. manihotis. In Cassava in the third millennium: Modern production, processing, use, and marketing systems (ed. Ospina Patino B, Ceballos H). Centro Internacional de Agricultura Tropical (CIAT), Denver, CO.

Wagaba H, Taylor N. 2018. Development and delivery of transgenic virus-resistant cassava in East Africa. In Genes, genetics and transgenics for virus resistance in plants (ed. Patil BL), pp. 159 176. Caister Academic, Poole, UK. doi:10.21775/9781910190814.08

Wagaba H, Beyene G, Aleu J, Odipio J, Okao-Okuja G, Chauhan RD, Munga T, Obiero H, Halsey ME, Ilyas M, 
Z.J.D. Lin et al.

et al. 2016a. Field level RNAi-mediated resistance to cassava brown streak disease across multiple cropping cycles and diverse East African agro-ecological locations. Front Plant Sci 7: 2060. doi:10.3389/fpls.2016.02060

Wagaba H, Patil BL, Mukasa S, Alicai T, Fauquet CM, Taylor NJ. 2016b. Artificial microRNA-derived resistance to cassava brown streak disease. J Virol Methods 231: 38-43. doi:10.1016/j.jviromet.2016.02.004

Wang A, Krishnaswamy S. 2012. Eukaryotic translation initiation factor $4 \mathrm{E}$-mediated recessive resistance to plant viruses and its utility in crop improvement. Mol Plant Pathol 13: 795-803. doi:10.1111/j.1364-3703.2012.007 91.x

Wang Y, Cheng X, Shan Q, Zhang Y, Liu J, Gao C, Qiu JL. 2014. Simultaneous editing of three homoeoalleles in hexaploid bread wheat confers heritable resistance to powdery mildew. Nat Biotechnol 32: 947-951. doi:10 $.1038 /$ nbt. 2969

Wang H, Beyene G, Zhai J, Feng S, Fahlgren N, Taylor NJ, Bart R, Carrington JC, Jacobsen SE, Ausin I. 2015. CG gene body DNA methylation changes and evolution of duplicated genes in cassava. Proc Natl Acad Sci 112: 13729-13734. doi:10.1073/pnas.1519067112

Wang HL, Cui XY, Wang XW, Liu SS, Zhang ZH, Zhou XP. 2016. First report of Sri Lankan cassava mosaic virus infecting cassava in Cambodia. Plant Dis 100: 1029-1029. doi:10.1094/PDIS-10-15-1228-PDN
Wilson MC, Mutka AM, Hummel AW, Berry J, Chauhan RD, Vijayaraghavan A, Taylor NJ, Voytas DF, Chitwood DH, Bart RS. 2017. Gene expression atlas for the food security crop cassava. New Phytol 213: 1632-1641. doi:10.1111/nph.14443

Wolfe MD, Rabbi IY, Egesi C, Hamblin M, Kawuki R, Kulakow P, Lozano R, Carpio DPD, Ramu P, Jannink JL. 2016. Genome-wide association and prediction reveals genetic architecture of cassava mosaic disease resistance and prospects for rapid genetic improvement. Plant $G e$ nome doi:10.3835/plantgenome2015.11.0118

Wydra K, Zinsou V, Jorge V, Verdier V. 2004. Identification of Pathotypes of Xanthomonas axonopodis pv. manihotis in Africa and detection of quantitative trait loci and markers for resistance to bacterial blight of cassava. Phytopathology 94: 1084-1093. doi:10.1094/PHYTO.2004.94.10 .1084

Wylie SJ, Adams M, Chalam C, Kreuze J, López-Moya JJ, Ohshima K, Praveen S, Rabenstein F, Stenger D, Wang A, et al. 2017. ICTV virus taxonomy profile: Potyviridae. $J$ Gen Virol 98: 352-354. doi:10.1099/jgv.0.000740

Yadav JS, Ogwok E, Wagaba H, Patil BL, Bagewadi B, Alicai T, Gaitan-Solis E, Taylor NJ, Fauquet CM. 2011. RNAimediated resistance to cassava brown streak Uganda virus in transgenic cassava. Mol Plant Pathol 12: 677-687. doi:10.1111/j.1364-3703.2010.00700.x 


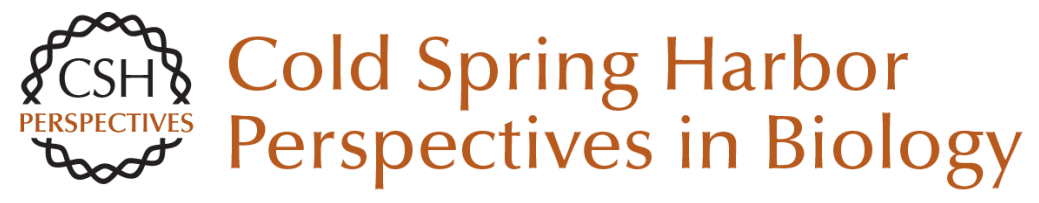

\section{Engineering Disease-Resistant Cassava}

\section{Z.J. Daniel Lin, Nigel J. Taylor and Rebecca Bart}

Cold Spring Harb Perspect Biol 2019; doi: 10.1101/cshperspect.a034595 originally published online June 10, 2019

\section{Subject Collection Engineering Plants for Agriculture}

Plant Inflorescence Architecture: The Formation, Activity, and Fate of Axillary Meristems Yang Zhu and Doris Wagner

Sub1 Rice: Engineering Rice for Climate Change Kyle Emerick and Pamela C. Ronald

Engineering Disease-Resistant Cassava Z.J. Daniel Lin, Nigel J. Taylor and Rebecca Bart

Many Facets of Dynamic Plasticity in Plants Xiaodong Yang and Sally A. Mackenzie

How Do Strigolactones Ameliorate Nutrient Deficiencies in Plants?

Kaori Yoneyama

Mechanisms and Impact of Symbiotic Phosphate Acquisition Chai Hao Chiu and Uta Paszkowski
The Sweet Side of Plant-Specialized Metabolism Thomas Louveau and Anne Osbourn

The Role of Dwarfing Traits in Historical and Modern Agriculture with a Focus on Rice Ángel Ferrero-Serrano, Christian Cantos and Sarah M. Assmann

Bt Brinjal in Bangladesh: The First Genetically Engineered Food Crop in a Developing Country Anthony M. Shelton, Md. J. Hossain, Vijay Paranjape, et al.

Circadian Rhythms in Plants Nicky Creux and Stacey Harmer

Developing Blight-Tolerant American Chestnut Trees William A. Powell, Andrew E. Newhouse and Vernon Coffey

Stomatal Development and Perspectives toward Agricultural Improvement Hitoshi Endo and Keiko U. Torii

For additional articles in this collection, see http://cshperspectives.cshlp.org/cgi/collection/

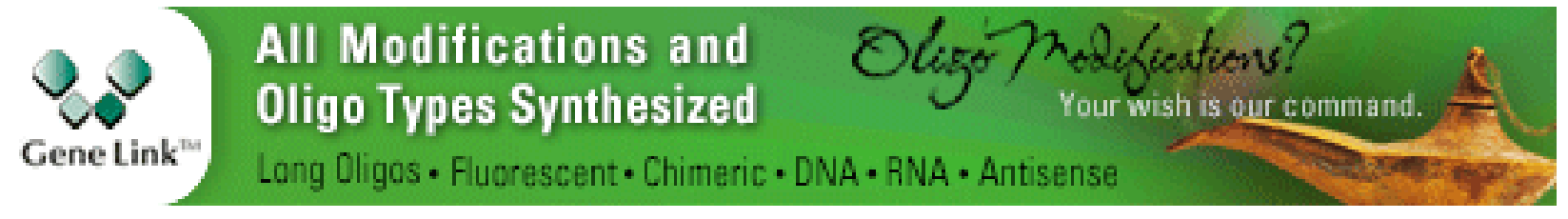

